\title{
REVIEW
}

\section{CONTRIBUTIONS TO RICKETTSIOSES RESEARCH IN COLOMBIA (1917-1943), LUIS B. PATIÑO CAMARGO}

\author{
Álvaro A. FACCINI-MARTÍNEZ(1,2,3,4), Carlos A. BOTERO-GARCÍA(5) \& Marylin HIDALGO(6)
}

\begin{abstract}
SUMMARY
Colombian physician Luis Benigno Patiño Camargo was one of the pioneers in the study of rickettsioses in South America, demonstrating for the first time in Colombia the presence of Rickettsia rickettsii as the etiological agent of a highly deadly exanthematic febrile syndrome in the 1930s. However, Patiño-Camargo performed other investigations from 1917-1943, which represent the first descriptions and scientific evidence of the presence of $R$. prowazekii and $R$. typhi in Colombia. Almost 60 years after the latest research conducted by Dr. Patiño-Camargo, rickettsioses were again a matter of interest and research. In the last decade over 20 research studies have been published, showing new endemic areas for $R$. rickettsii, as well as the description of new rickettsial species in Colombia.
\end{abstract}

KEYWORDS: Rickettsia infections; Colombia; Rickettsia rickettsii; Rickettsia prowazekii; Rickettsia typhi.

\section{INTRODUCTION}

Rickettsioses are zoonotic infectious diseases caused by pathogenic bacteria of the genus Rickettsia and Orientia transmitted to human beings through arthropod vectors (ticks, fleas, mites and lice) ${ }^{1}$. Currently in the Americas, such diseases are recognized as emerging and re-emerging due to the description of new species of Rickettsia, vectors and clinical syndromes ${ }^{2,3}$.

The Colombian physician Luis Benigno Patiño Camargo (1891-1978) is a historical icon in the field of tropical medicine and public health in Colombia ${ }^{4}$. He was a pioneer in the study of rickettsioses in South America, demonstrating for the first time the presence of $R$. rickettsii as an etiological agent of an exanthematic febrile syndrome of high mortality in Colombia ${ }^{5,6}$. Patiño-Camargo also conducted other investigations which represent the first descriptions and scientific evidence of the presence of $R$. prowazekii and $R$. typhi in Colombia ${ }^{7,8}$, which seem to be unknown internationally.

This manuscript presents the contributions of Patiño-Camargo to rickettsiology in Colombia between 1917 and 1943, and new contributions to this field since then.

\section{Epidemic typhus in Bogotá}

"But we, on scientific matters do not accept but proven facts."
The duality of typhoid diseases (typhoid fever and epidemic typhus) in Bogotá has been discussed since 1630. However, in 1901 the prestigious Colombian physician Dr. Lombana-Barreneche proposed that typhoid fever was the only typhoid disease in the city ${ }^{9}$. To refute Dr. Lombana-Barreneche and validate the historical record, Dr. PatiñoCamargo conducted his clinical and experimental studies between 1917 and 1922, proving the presence of epidemic typhus in Bogotá. This thesis gave him the title of Doctor in Medicine. The most relevant findings of his degree work are presented below ${ }^{7,10}$.

Diagnostic description of 67 clinical cases compatible with typhoid disease in Bogotá since 1918 to 1922: 23 cases (34.3\%) of epidemic typhus (based on negative blood cultures to Salmonella typhi and typical febrile reaction in guinea pigs inoculated with blood and/ or "Pediculus vestimenti" of patients); 14 cases $(20.8 \%)$ of typhoid fever (positive blood cultures and serum agglutination to $S$. typhi); three cases $(4.4 \%)$ of co-infection Typhoid fever/ Epidemic typhus (positive blood cultures to $S$. typhi and typical febrile reaction in guinea pigs inoculated with blood of patients) and $27(40.2 \%)$ cases with inconclusive diagnoses (negative blood cultures and serum agglutination to $S$. typhi, and negative experimental studies in guinea pigs).

Clinical description of Epidemic typhus in Bogotá: “...periodic fever, profound organic disturbance mainly of the nervous centers and of the respiratory apparatus, and an early eruption. The incubation period as a rule is five days, but may last from 2 to 25 days. Main symptoms are:

(1) Servicios y Asesorías en Infectología (SAI), Bogotá, Colombia.

(2) Universidad de La Sabana, Facultad de Medicina, Bogotá, Colombia.

(3) International Society for Chemotherapy (ISC), Working Group on Zoonoses, Aberdeen, UK.

(4) Comité de Zoonosis y Fiebres Hemorrágicas, Associación Colombiana de Infectologia (ACIN), Bogotá, Colombia.

(5) Universidad Militar Nueva Granada, Facultad de Medicina, Bogotá, Colombia.

(6) Pontificia Universidad Javeriana, Facultad de Ciencias, Departamento de Microbiología, Bogotá, Colombia.

Correspondence to: Dr. Álvaro A. Faccini-Martínez. Servicios y Asesorías en Infectología (SAI), Calle 50 \# 13-62, Bogotá, D.C., Colombia.

Phone: +57 1 2485357. E-mail: afaccini@gmail.com 
constrictive cephalalgia, rachialgia, myalgia, and chills. The pulse is fast, intermittent, and depressible. The temperature rises rapidly and in a few hours may reach $40^{\circ} \mathrm{C}$. The average duration of the fever is fifteen days. Flushed face, conjunctival injection, coated tongue but with edges and red tip; early appearance of rash on the trunk and abdomen, often extending to the extremities: lenticular spots which are generalized and become multiform and polychromic petechiae, ending in a bran-like desquamation of the epidermis; constipation, exceptionally diarrhea and marked abdominal distension. In the usual fatal case there is vomiting, jaundice, and albuminuria; bronchopulmonary involvement; stupor; constant and severe nervous system symptoms; early cardiovascular symptoms; leukocytosis".

The histopathological description of the findings of a patient that died with a diagnosis of epidemic typhus: I) dissection of an arterial lesion: “....arteriole sealed by a thrombus of necrotic cells and white blood cells and red blood cells grouped in the fibrinous inflammatory exudate. The endothelial inflammatory process is clearly noted in all its phases of cellular infiltration, desquamation, proliferation, necrosis and wall destruction. The periarteritis phenomenon is clearly seen”. II) Dissection of skin: "...extensive perivascular infiltration of leukocytes and so called wandering cells or macrophages around a vessel of sweat glands in the skin of the chest. The walls are in process of disintegration by the inflammatory process". "We have seen in other samples the process of perivasculitis and vasculitis result in complete vessel occlusion with necrosis and destruction of the walls and consequential bleeding".

The conclusions of the research were presented in the Sixth Congress of Pacific Sciences in 1939, as follows ${ }^{10}$ :

1. Typhus was transmitted to guinea pigs by inoculating blood from the patients in the first days of the disease.

2. The "virus" was conserved by means of serial transfers in guinea pigs.

3. The infection was transmitted to guinea pigs by the injection of triturated lice.

4. Transmission to guinea pigs was accomplished with infected human lice.

5. It was observed that, after an incubation of five to 15 days, the "virus" causes fever in the guinea pigs as high as $41^{\circ} \mathrm{C}$ for periods varying from 4 to 7 days. No scrotal reaction was observed. The mortality of the experimentally infected animals was very low.

6. Human autopsies revealed histological vascular lesions of the skin and brain, and very characteristic nodules in brain sections.

\section{Third outbreak of petechial fever in the Americas}

"Epidemically, clinically, and experimentally it is different from the black typhus, being more similar in many ways to Rocky Mountain spotted fever of North America and to São Paulo typhus of Brazil." 10

In May 1935, while Dr. Patiño-Camargo worked as chief of the Colombian Department of Yellow Fever, he was notified about an outbreak limited to the village of Tobia, Cundinamarca $\left(5^{\circ} 07^{\prime} 22^{\prime \prime} \mathrm{N}\right.$ $74^{\circ} 27^{\prime} 01$ "O located approximately $70 \mathrm{~km}$ from Bogotá, 750 meters above the sea level, mainly characterized by its large sugar cane crops, as well as other tubers and fruit trees), that consisted of a febrile illness of high mortality. In the following months serological and histopathological studies were conducted which ruled out yellow fever as the etiology, and conversely, in association with the National Department of Hygiene of Colombia and the International Health Division of the Rockefeller Foundation, it was confirmed by experimental methods in an animal model, the presence of a "rickettsiosis of the spotted fever group" as the etiology ${ }^{5,10}$. According to data from the Colombian Department of Yellow fever, between July 1934 to August 1936, 65 people were victims of the febrile illness with a rate case-fatality of $95 \%(62 / 65)$, and most deaths occurred in the age group between 20-29 years and in the months of July, February, March and April $1^{5,10}$.

The clinical findings were described as follows ${ }^{10}$ : "The average prodromal period is of about two days and is characterized by indisposition, dizziness, and general malaise. The onset is abrupt. Among the 62 cases studied, the duration of illness varied from 4 to 10 days." "The dominant symptoms are the following: rachialgia, arthralgia, and myalgia; chills; nausea and vomiting; photophobia and conjunctival congestion; white, dry, and trembling tongue; red at the tip and on the edges; slight jaundice; marked constipation, early nervous symptoms: indifference, stupor, agitation... high fever with slight morning remissions; rapid pulse. The eruption is a pathognomonic sign; it appears early and rapidly becomes generalized, and is centripetal, appearing first on the hands, feet, and face, and spreading to all the body including the scalp; the spots are papular, rose-colored, violet, or frankly hemorrhagic; on the cheeks it is confluent and forms red patches. The cadavers have a characteristic appearance and are covered with violet spots."

Some conclusions of the experimental studies in animal model were the following ${ }^{10}$ : the disease can be transmitted to laboratory animals by injecting the blood of patients, and the "virus" can be conserved indefinitely by serial transfers of the blood or of suspensions of tissues. It is fatal to white rats, rabbits, and monkeys (Macacus rhesus).

In inoculated guinea pigs the incubation lasts two days. The fever period lasts from four to 14 days. In the first passages the males show a scrotal reaction with hemorrhagic spots, inflammation, and edema, while the females show congestion and inflammation of the external genitals. In guinea pigs the mortality is 96 per cent.

From the first series of inoculated animals, smears made from scrapings of the peritoneum showed the endothelial cells parasitized by a microorganism having all the characteristics of rickettsiae.

The main macroscopic lesions in sacrificed experimental animals are: subcutaneous edema, hypertrophy of lymph nodes, serous effusions which are sometimes tinged with blood, hyperemia and punctate hemorrhages of the mesentery, congestion of the spleen, kidneys, and suprarenal glands, and sometimes of the lung and brain.

Preliminarily, after field studies in the epidemic area, it was considered that this was a disease that was present in households, was sporadic, and its probable vector were ticks of the genus Ornithodorus, as they were the predominant ectoparasites in homes and beds of the victims with the disease $\mathrm{e}^{5,10}$. Thereafter, between 1940 and 1941 Dr. Patiño-Camargo had the chance of looking into two new cases compatible with exanthematic rickettsiosis, from areas close to the village of Tobia. Both patients died in Bogotá and their blood was used to inoculate guinea pigs, which presented a typical febrile reaction and orchitis on the fifth day post-inoculation. In the slides with peritoneal scraping smears from animals, stained by the method of Giemsa, polymorphic 
intracytoplasmic rickettsiae were found, with a predominance of coccoid forms. Two isolates were obtained, called "G1 Virus" and "L2 Virus", which were kept in animal passages together with the Rocky Mountain Laboratory in Hamilton (Montana, USA), in association with Dr. Ralph Robinson Parker ${ }^{6}$.

In turn, in October 1940 and January 1941 two isolates were obtained from Amblyomma cajennense ticks, captured on a mule in the village of Tobia and on the corpse of the patient that originated the "Virus L2". The latter, called "Virus L3", was isolated from intraperitoneal inoculation of the crushed ticks in the guinea pig. The animal developed fever on the fifth day, hypothermia and died on the tenth day post-inoculation. With the above data, Dr. Patiño-Camargo suggested A. cajennense tick as the natural vector of the disease in the region of Tobia and its surroundings ${ }^{6}$.

\section{New outbreak of epidemic typhus in Bogotá}

"And I've waited 24 years patiently for the awakening of the Typhus of its long endemic slumber and for it to stand face to face before clinicians..."11

In early 1940 and 1941 the first signs of the re-emergence of epidemic typhus revealed themselves in Bogotá thanks to the appearance of suggestive cases of typhoid fever and measles, respectively for each year ${ }^{11}$. However, a new outbreak of the disease was not described until July 1941. A total of 20 patients were affected between the $1^{\text {st }}$ of July and the $19^{\text {th }}$ of August on the same year ${ }^{11}$. These cases were evaluated clinically and experimentally confirmed by Dr. Patiño-Camargo through the Weil-Félix agglutination test (titers from 1:320 to 1:1024) and the intraperitoneal inoculation of guinea pigs with blood, organs and lice from patients, resulting in the isolation of four "viral" strains ${ }^{11}$.

Interestingly, Patiño-Camargo also noted that in the context of a patient with a clinical picture suggestive of epidemic typhus, the presence in the blood count of leukocytosis higher than 10,000, neutrophils higher than $80 \%$ and absence of eosinophils, were para-clinical data characteristic of the disease. He suggested that leukocytosis higher than 30,000 was a predictor of mortality, while the decrease in leukocytosis and the appearance of eosinophils in the course of the disease were prognostic of a benign course ${ }^{11}$.

\section{Spotted fever in Northern Caldas}

"This clinical course allows the clinician to eliminate the diagnostic of typhoid fever and formulate with all reason and justice the one of typhoexanthematic rickettsiosis, that is my diagnosis of the outbreak of Caldas." 12

In the North of the department of Caldas $\left(5^{\circ} 06^{\prime} \mathrm{N} 75^{\circ} 33^{\prime} \mathrm{O}\right)$, according to medical reports, from 1924, isolated outbreaks of a febrile illness presented, presumptively classified as typhoid fever, affecting more than 2,000 people from 1940 to 1941 with a mortality of $2-18 \%{ }^{12}$. Therefore, Dr. Patiño-Camargo was invited to study the epidemic disease suspected of being murine typhus. His studies were conducted between February the $27^{\text {th }}$ to March the $4^{\text {th }}, 1942$, and at that time he examined and collected clinical samples from patients of the municipalities of Neira, Aranzazu, Salamina, Pácora and Aguadas. He ruled out typhoid fever as the main etiology by finding the persistence of cases despite water sanitation measures and the incidence in equal proportions in vaccinated and unvaccinated patients against the typhoid bacillus.

He described the clinical findings as follows: abrupt onset of disease, initial fever up to $40{ }^{\circ} \mathrm{C}$, lasting from 8 to 18 days (mean 15 days). Rapid pulse and hypotension, generalized rash that appears on the third day, sometimes papular, multiform and polychromatic, affecting palms and soles. There was constipation. Very acute forms presented stupor and delirium. Vasodilatation of the face and conjunctival injection ${ }^{12}$ were present. At the same time, serological tests were performed in 22 cases, showing in 15 of them positive results for the Weil-Félix test, one patient had a positive Widal test and the remaining six had undeterminate test results $^{12}$. Finally, he managed to isolate the etiological "virus" in guinea pigs by intraperitoneal inoculation of blood from a patient. Guinea pigs presented experimental disease on the eighth day post-inoculation and coccobacilli forms suggestive of Rickettsia were observed in peritoneum samples and tunica vaginalis stained with Giemsa ${ }^{12}$

\section{Murine typhus in Bogotá}

\section{"Apparently it is the endemic virus transmitted by fleas and preserved} in wild rats" 8

In early October 1941, Dr. Patiño-Camargo met a patient hospitalized for an exanthematic febrile illness, who worked in a wood company in Bogotá. Faced with suspected typhoid disease, he inoculated the blood of the patient in three guinea pigs, of which one developed a fever of $41{ }^{\circ} \mathrm{C}$ associated with severe orchitis at day 12 post-inoculation. In the tunica vaginalis and the peritoneum of the sacrificed animal abundant rickettsias were found ${ }^{8}$. The patient presented a benign course of illness and a positive Weil-Félix test (1:640) during convalescence ${ }^{8}$. In the wood company where the patient worked, 22 rats were captured (Rattus rattus and $R$. norvegicus) and fleas were taken from the rats. Crushed brain tissue from the captured rodents and a pool of 61 fleas were used to inoculate guinea pigs. Four animals presented fever and typical orchitis ${ }^{8}$.

Subsequently, in April 1942, Dr. Patiño-Camargo was informed about a new case with suspected murine typhus. It was a 56-year-old male, employee of a coffee, leather and wood warehouse of Bogotá, with a febrile illness of 16 days, associated with conjunctival injection, generalized exanthematic eruption, with no face involvement, pulmonary congestion with expectoration, adynamia, mental obnubilation and semi-comatose state ${ }^{8}$. Blood samples from the patient and fleas were caught in the workplace and sent to the laboratory, these samples were used to inoculate six guinea pigs, four of them presented typical febrile reaction and one animal had fever and orchitis. Endothelial rickettsiae were observed in the sacrificed animals ${ }^{8}$.

Finally, in the period from April the $29^{\text {th }}$ to June the $29^{\text {th }}, 1942$, there was an outbreak of a febrile illness in a school in downtown Bogotá, affecting seven people among students and teachers. All the cases occurred in women, with benign disease progression; four cases presented exanthema, predominant in abdomen and extremities ${ }^{8}$. Six cases presented a positive Weil-Félix test OX19 (1:100 to 1:800) and none of the patients presented a positive Widal test ${ }^{8}$. From the $9^{\text {th }}$ to the $17^{\text {th }}$ of July of the same year, in the school premises, $R$. norvegicus rats were captured and more than 160 fleas in order to perform experimental inoculations. Seven guinea pigs inoculated with macerated fleas and 
organs (brain, spleen and adrenal glands) of sacrificed rats presented typical febrile reaction and orchitis. Endothelial rickettsiae were observed in the sacrificed animals ${ }^{8}$.

\section{New contributions after Patiño-Camargo}

Almost 60 years after the last investigations conducted by Dr. Patiño-Camargo, interest in the study of rickettsioses regained strength in Colombia. In Table 1 the contributions made from 2001 to June 2015 are presented.

\section{CONCLUSIONS}

It is clear that the scientific research conducted by Dr. PatiñoCamargo during 1917-1943 not only accounted for the first evidence in Colombia of $R$. rickettsii, but also the finding of other rickettsioses, mainly the typhus group rickettsiae ( $R$. prowazekii and $R$. typhi), in different regions of the country ${ }^{5,6,7,8,10,11,12}$. In fact, the department of Cundinamarca ${ }^{15,16,21,33}$ and Caldas ${ }^{18,29,30}$ are currently considered endemic areas for SFG and flea-borne rickettsioses, respectively.
On the other hand, in the last decade in Colombia more than 20 research studies have been published, describing new endemic areas for $R$. rickettsii in Northwestern Colombia ${ }^{14,19,23}$, as well as the description of the presence of other Rickettsia (R. bellii, Rickettsia sp. strain Colombianensi, R. felis and Rickettsia sp. strain Atlantic rainforest $)^{25,30,31,32}$, the latter two are classified as human pathogens ${ }^{36,37}$. The above data imposes new challenges from the clinical and diagnostic perspectives, given the existence of possible cases of rickettsiosis associated with inoculation eschar (related to Rickettsia sp. strain Atlantic rainforest), and the role of species transmitted by fleas $(R$. typhi and $R$.felis) as probable secondary etiologies of the acute febrile syndrome in different regions of Colombia.

Finally, despite all the evidence and the recent interest in research on these pathogens, describing new endemic areas, their vectors and the diseases they cause, it has not yet been possible to place them among national priorities. As a result, they are frequently underdiagnosed as they are not commonly suspected. The aim of this manuscript was to call the attention of national and international scientific communities to emphasize the importance and relevance of these pathologies, something

Table 1

Contributions made to the study of rickettsioses in Colombia, 2001-2015

\begin{tabular}{lccc}
\hline Year of publication & Title & Author & Relevant Findings \\
\hline & "Alta seroprevalencia de & & \\
rickettsiosis en trabajadores & Miranda & - Seroprevalence of 49\% for the spotted fever group (SFG) (IgG-R. conorii) in \\
del campo en el municipio de & et al. ${ }^{13}$ & a rural population of the municipality of Ciénaga de Oro, Córdoba.
\end{tabular}
Ciénaga de Oro, Córdoba"

"Brote de rickettsiosis en Necoclí, Antioquia, febreromarzo de 2006"

Acosta et al. ${ }^{14}$

- Fourteen compatible cases of rickettsiosis by $R$. rickettsii (five soldiers and nine civilians) in Necoclí, Antioquia. Lethality of $35 \%$ (five deaths). Nine confirmed cases (four by serology, three by immunohistochemistry /PCR and two by epidemiological link). - Most frequent clinical aspects: fever (100\%), headache (93\%), arthralgia (71.4\%), tachycardia (71.4\%), abdominal pain $(57 \%)$, diarrhea $(50 \%)$, vomiting $(36 \%)$, and exanthema $(7 \%)$. - Most frequent para-clinical aspects: thrombocytopenia (71\%), leukopenia (64\%), hemoconcentration (21\%), monocytosis (21\%), band cells and atypical lymphocytes $(14 \%)$.

- Years 2003-2004, nearby regions to Tobia and Villeta, Cundinamarca: two fatal cases of infection by $R$. rickettsii, 2007 Rocky Mountain Spotted Hidalgo confirmed by molecular methods and immunohistochemistry. - Retrospective study: seroprevalence of SFG (IgM e IgG-R. rickettsii) $1.5 \%$ and $4.7 \%$, respectively, nationally (departments of Santander, Guaviare y Caldas), and of $20.8 \%$ and $21.9 \%$, respectively, in the department of Cundinamarca.

\begin{tabular}{|c|c|c|c|}
\hline 2007 & $\begin{array}{l}\text { Prevalence of antibodies } \\
\text { against Spotted Fever group } \\
\text { rickettsiae in a rural area of } \\
\text { Colombia }\end{array}$ & $\begin{array}{l}\text { Hidalgo } \\
\text { et al. }{ }^{16}\end{array}$ & $\begin{array}{l}\text { - } 2005 \text {, rural population, } 22 \text { villages in the municipality of Villeta, } \\
\text { Cundinamarca: Seroprevalence of the SFG (IgG- } \text {. rickettsii): } 40.3 \% \text { (from } \\
1: 64 \text { to } 1: 1,024) \text {. }\end{array}$ \\
\hline 2007 & $\begin{array}{l}\text { "Tifus murino en el Cairo- } \\
\text { Valle ¿Brote o condición } \\
\text { endémica emergente?” }\end{array}$ & $\begin{array}{l}\text { Ramírez } \\
\text { et al. }{ }^{17}\end{array}$ & $\begin{array}{l}\text { - } 19 \text { suggestive cases of murine typhus; } 11 \text { cases with positive Weil- } \\
\text { Félix test (from 1:80 to } 1: 360 \text { ) of which three were confirmed by indirect } \\
\text { immunofluorescence test. }\end{array}$ \\
\hline 2008 & $\begin{array}{l}\text { Murine typhus in Caldas, } \\
\text { Colombia }\end{array}$ & $\begin{array}{l}\text { Hidalgo } \\
\text { et al. }^{18}\end{array}$ & $\begin{array}{l}\text { - 2005, Northern Caldas, } 120 \text { patients with acute febrile syndrome and } \\
\text { positive Weil-Félix test }(1: 320) \text { of which } 14 \text { were confirmed by indirect } \\
\text { immunofluorescence test in paired samples (IgG seroconversion- } R \text {. typhi). }\end{array}$ \\
\hline
\end{tabular}


Table 1

Contributions made to the study of rickettsioses in Colombia, 2001-2015 (cont.)

\begin{tabular}{|c|c|c|c|}
\hline Year of publication & Title & Author & Relevant Findings \\
\hline 2008 & $\begin{array}{l}\text { "Estudio de brote febril } \\
\text { hemorrágico en el } \\
\text { corregimiento de Alto } \\
\text { de Mulatos - Distrito } \\
\text { Especial Portuario de Turbo, } \\
\text { Antioquia, enero de 2008" }\end{array}$ & $\begin{array}{c}\text { Pacheco-García } \\
\text { et al. } .^{19}\end{array}$ & $\begin{array}{l}\text { - Fifteen cases compatible with rickettsiosis by } R \text {. rickettsii (rural } \\
\text { population) in Turbo, Antioquia. Lethality of } 26.6 \% \text { (four deaths). } \\
\text { Six confirmed cases (serology) and nine by epidemiological link. } \\
\text { - Most frequent clinical aspects: Fever }(100 \%) \text {, myalgias }(86.7 \%) \text {, } \\
\text { vomiting }(60 \%) \text {, arthralgias }(60 \%) \text {, abdominal pain y headache }(53.3 \%) \text {, } \\
\text { retro-orbital pain }(33.3 \%) \text {, jaundice }(26.7 \%) \text {, and exanthema }(20 \%) \text {. } \\
\text { - Most frequent para-clinical aspects: thrombocytopenia and elevated } \\
\text { transaminases }(100 \%) \text {, elevated creatinine }>1.4 \mathrm{mg} / \mathrm{dl}(50 \%) \text {. }\end{array}$ \\
\hline
\end{tabular}

"Seroprevalencia de Leptospira sp., Rickettsia

$2008 \quad$ sp. y Ehrlichia sp. en

Ríos - 2004, department of Sucre, rural population: Seroprevalence of Rickettsia trabajadores rurales del et al. ${ }^{20} \quad$ sp. (indirect immunofluorescence test-IgG) $-7.8 \%$.

departamento de Sucre,

Colombia",

A survey of antibodies against Rickettsia rickettsii

2009 and Ehrlichia chaffeensis Hidalgo in domestic animals from a et al. ${ }^{21}$ rural area of Colombia

Geographic variation in risk 2009 factors for SFG rickettsial and leptospiral exposure in

Padmanabha et al. ${ }^{22}$ Colombia
Outbreak of Rocky Mountain Spotted Fever in Córdoba, Colombia
Hidalgo et al. $^{23}$
- 2008, Villeta, Cundinamarca, serum from 22 dogs and 159 horses: Seroprevalence of the SFG (IgG-R. rickettsii Taiaçu strain) - 18.2\% (from 1:64 to $1: 4,096$ ) and $16.3 \%$ (from 1:64 to 1:8,192) for dogs and horses, respectively.

- Necoclí, Antioquia, human population: Seroprevalence of the SFG (IgG- $R$. rickettsii Sheila Smith strain) between $16.7 \%$ and $44.1 \%$. Isolated rural housing was the only independent variable associated with exposition to Rickettsiae of the SFG.

- 2007, 11 cases compatible with rickettsiosis by $R$. rickettsii in Los Córdobas, Córdoba. Eleven confirmed cases (four by immunohistochemistry and seven by serology). Lethality of $36 \%$ (four deaths). - Most frequent clinical aspects: Fever and headache (94\%), retro-orbital pain $(88 \%)$, arthralgias $(72 \%)$, malaise $(66 \%)$, myalgias $(61 \%)$, abdominal pain $(61 \%)$, vomiting $(55 \%)$, diarrhea $(44 \%)$, and exanthema $(18 \%)$. - Most frequent para-clinical aspects: neutrophilia (60\%), leukocytosis (50\%), thrombocytopenia (40\%).

"Vigilancia de la infección por Rickettsia sp. en capibaras (Hydrochoerus

2011 hydrochaeris) un modelo potencial de alerta epidemiológica en zonas endémicas"

Rickettsia sp. Strain

Colombianensi (Rickettsiales: Rickettsiaceae): A New proposed Rickettsia

2012 Detected in Amblyomma dissimile (Acari. Ixodidae) From Iguanas and FreeLiving Larvae Ticks From Vegetation

"Ecoepidemiología de la infección por rickettsias en roedores, ectoparásitos y humanos en el noroeste de Antioquia, Colombia"
- 2009, Montería, Córdoba: sera of 36 capybaras analyzed by indirect Miranda $e$ immunofluorescence test (IgG- $R$. rickettsii Taiaçu strain), of which $22 \%$ $t_{a l}{ }^{24} \quad$ presented seropositivity for the SFG (1:64 to1:512). 933 ticks were captured from the capybaras; all classified taxonomically as A. cajennense.
- 2009, Montería, Córdoba: 16 pools of $A$. dissimile (captured from iguanas) and 12 pools of larvae captured on vegetation (six Amblyomma sp. and Rhipicephalus microplus) were positive for amplification of conserved genes in the genus Rickettsia ( $g l t A$, ompA, ompB) with high similarity to $R$. monacensis and $R$. tamurae. According to the percentage of similarity of the evaluated genes a new species is proposed (Rickettsia sp. strain colombianensi).

- Three municipalities of the Urabá Antioqueño (Apartadó, Turbo and Necoclí): Seropositivity for the SFG (IgG- $R$. rickettsii) of $43 \%$ in rodents and $24 \%$ in
Quintero et al. ${ }^{26}$ humans. Amplification of the gltA gene from a liver sample of rodents $(6.8 \%)$ with a similarity of $98.7 \%$ for $R$. prowazekii. Amplification of the gltA gene from larvae of Amblyomma sp. with a similarity of $>99 \%$ for $R$. tamurae. 
Table 1

Contributions made to the study of rickettsioses in Colombia, 2001-2015 (cont.)

\begin{tabular}{llll}
\hline Year of publication & Title & Author & Relevant Findings
\end{tabular}

- 16-year-old patient, from the urban area of the municipality of Útica, Cundinamarca, with acute febrile syndrome of three days of evolution;

"Caso probable de fiebre

2013 manchada (Rickettsia felis) transmitida por pulgas"

Faccini-Martínez et al. ${ }^{27}$ leukopenia and thrombocytopenia; benign clinical course in the absence of antimicrobial therapy; negative IgM for dengue; seroconversion by indirect immunofluorescence test (IgG-R. felis) in paired samples $(<1: 64$ and 1:256, respectively).

- Years 2007-2008, a total of 220 patients with non-malaric febrile syndrome, from the municipalities of Necoclí, Turbo and Apartadó: Diagnosis of rickettsiosis of the SFG (IgG- $R$. rickettsii in paired samples) by seroconversion
"Etiología y caracterización epidemiológica del síndrome

2013 febril no palúdico en tres municipios del Urabá antioqueño, Colombia"
Arroyave et al. ${ }^{28}$ in $2.7 \%$ of the cases; co-infection rickettsiosis-dengue in $0.9 \%$ of the cases and co-infection rickettsiosis-dengue-leptospirosis in $0.4 \%$ of the cases. - Most frequent clinical features in patients with rickettsiosis of the SFG: Fever, headache, myalgia and arthralgia (100\%), abdominal pain and anorexia $(66.7 \%)$, retro-orbital pain $(50 \%)$, jaundice and exanthema $(33.3 \%)$, respiratory distress, cardiopulmonary impairment and mental confusion (16.7\%).

- Years 2010-2011, humans from seven municipalities of Northern Caldas: seroprevalence by indirect immunofluorescence test of $17.8 \%$ for $R$. felis (IgG-R. felis Pedreira strain), of $25.2 \%$ for $R$. typhi (IgG-R. typhi Wilmington
Flea-Borne Rickettsioses in

2013 the North of Caldas Province, Colombia
Hidalgo et al. ${ }^{29}$ strain) and of $28.7 \%$ for both species. Twenty six cases of acute febrile syndrome compatible with rickettsiosis, of which nine were confirmed by seroconversion in paired samples (two murine typhus, one infection by $R$. felis, one as Flea-borne rickettsiosis and five as SFG-Rickettsiosis [IgG- $R$. rickettsii Taiaçu strain]).

- Years 2010-2011; 1,341 fleas captured in seven municipalities of Northern

Molecular Detection of Rickettsia felis in Different Flea Species from Caldas,

Ramírez-

Hernández et al..$^{30}$ Colombia

Molecular detection of Rickettsia bellii and Rickettsia sp. strain

2014 Colombianensi in Ticks from Cordoba, Colombia

Miranda et al. ${ }^{31}$
"Infection of Amblyomma ovale by Rickettsia sp. strain Atlantic rainforest, Colombia"
Londoño et al. ${ }^{32}$ Caldas: detection of $R$. felis (amplification of the genes gltA, ompB and $17 \mathrm{kD}$ ) from Ctenocephalides felis, $C$. canis and Pulex irritans with infection rates of $5.3 \%, 9.2 \%$ and $10 \%$, respectively.

- 2009, 1069 A. cajennense ticks from capybaras (Montería) and 478 Amblyomma sp. ticks from vegetation (Los Córdobas), Córdoba: In five pools of larvae of Amblyomma sp. was detected R. bellii (gltA gene amplification) and in a pool of $A$. cajennense ticks was detected Rickettsia sp. strain Colombianensi (gltA, ompA y ompB gene amplification).

- Years 2010-2011, Turbo, Necoclí and Los Córdobas (northwestern Colombia): Molecular detection ( $\mathrm{glt}$, ompA у $о т p B$ gene amplification) and isolation of Rickettsia sp. strain Atlantic rainforest from nymphs caught in a dog and in a Tome's spiny rat (Proechimys semispinosus) from Necoclí, Antioquia. - Seven sequences of gltA gene compatible with Rickettsia sp. strain Atlantic rainforest from A. ovale ticks captured on vegetation (Los Córdobas), in Tome's spiny rat (Necoclí) and in dogs (Turbo).

-August 2013, 15 A. patinoi ticks captured from cattle in Naranjal village, Villeta, Cundinamarca: Isolation (Shell vial technique) and molecular characterization and $\operatorname{csp} A-k s g A$ ) of $R$. rickettsii (strain Villeta) from a female of $A$. patinoi. - Successful experimental infection (typical febrile reaction, scrotal necrosis and antibody production against $R$. rickettsii) in guinea pigs (3 passages) inoculated with $R$. rickettsii strain Villeta. - Detection of R. bellii in A. ovale ticks captured on a donkey in Necoclí, Antioquia. ( $g l t A, o m p A$ and $o m p B$ genes; intergenic regions RR0155-rpmB, RR1240-tlc $5^{b}$
2015

Rickettsia rickettsii in Amblyomma patinoi Ticks, Colombia
Faccini-Martínez et al. ${ }^{33}$
- 2012, 190 individuals of an indigenous reservation of the municipality of
Barrera et al. ${ }^{34}$
2015
Tuchín, Córdoba: seroprevalence of $5.2 \%$ for rickettsiae of the SFG (IgG- $R$. rickettsii Taiaçu strain) by indirect immunofluorescence test.
"Seroprevalencia de Hantavirus, Rickettsia y Chikungunya en población indígena del municipio de Tuchín, Córdoba “ 
Table 1

Contributions made to the study of rickettsioses in Colombia, 2001-2015 (cont.)

\begin{tabular}{|c|c|c|c|}
\hline Year of publication & Title & Author & Relevant Findings \\
\hline 2015 & $\begin{array}{l}\text { "Caso probable de tifus } \\
\text { murino con falla ventilatoria } \\
\text { en una adolescente del área } \\
\text { urbana de Cali, Colombia" }\end{array}$ & $\begin{array}{l}\text { Patiño-Niño } \\
\quad \text { et al. }{ }^{35}\end{array}$ & $\begin{array}{l}\text { - Case of a 13-year-old female patient, from the urban area of Cali, who } \\
\text { presented with fever associated to tachypnea and generalized maculopapular } \\
\text { exanthema on the trunk and limbs. During the first } 48 \text { hour in the pediatric } \\
\text { ICU she developed a rapid clinical deterioration, persistent fever, increased } \\
\text { acute phase reactants, bilateral interstitial pulmonary infiltrates and pleural } \\
\text { effusion requiring noninvasive ventilation. Treatment with doxycycline was } \\
\text { initiated due to a suspected possible infection by rickettsial agents. Twenty- } \\
\text { four hours later the patient presented clinical improvement, resolution of the } \\
\text { exanthema and removal of non-invasive ventilation. By means of indirect } \\
\text { immunofluorescence test, titers of 1:512 were shown against typhus group, } \\
\text { noting the probable diagnosis of murine typhus. }\end{array}$ \\
\hline
\end{tabular}

that Dr. Patiño-Camargo noted and proved with his research almost 100 years ago.

\section{CONFLICT OF INTEREST}

The authors declare that there is no conflict of interest

\section{REFERENCES}

1. Merhej V, Raoult D. Rickettsial evolution in the light of comparative genomics. Biol Rev Camb Philos Soc. 2011;86:379-405.

2. Hidalgo M, Faccini-Martínez ÁA, Valbuena G. Rickettsiosis transmitidas por garrapatas en las Américas: avances clínicos y epidemiológicos, y retos en el diagnóstico. Biomedica. 2013;33:161-78.

3. Faccini-Martínez ÁA, García-Álvarez L, Hidalgo M, Oteo JA. Syndromic classification of rickettsioses: an approach for clinical practice. Int J Infect Dis. 2014;28:126-39.

4. Patiño JF. Un hombre, un instituto. Biomedica(Bogotá). 2011;31 Supl 2:13-5.

5. Patino L, Afanador A, Paul JH. A spotted fever in Tobia, Colombia: preliminary report. Am J Trop Med. 1937;17:639-53.

6. Patiño-Camargo L. Nuevas observaciones sobre un tercer foco de fiebre petequial (maculosa) en el hemisferio Americano. Bol Ofic Sanit Panamericana. 1941;20:111224.

7. Patiño-Camargo L. El Tifo Negro o Exantemático en Bogotá. Bogotá: Editorial Cromos; 1922.

8. Patiño-Camargo L. Tifo Murino en Bogotá. Rev Fac Med. 1943;11:503-14.

9. Lombana-Barreneche JM. Septisemia eberthiana. Rev Méd Bogotá. 1901;256:127-40.

10. Patiño-Camargo L. Diseases of the Typhus Group in Colombia. The Sixth Pacific Science Congress. Science. 1939;89:681-94.

11. Patiño-Camargo L. Brote epidémico de tifo negro o exantemático en Bogotá. Rev Fac Med. 1941;10:1-12.

12. Patiño-Camargo L. El tifo exantemático en la hoya del rio Cauca. Rev Fac Med. 1942;9:1-9.
13. Miranda AM, Flórez S, Mattar S. Alta seroprevalencia de rickettsiosis en trabajadores del campo en el municipio de Ciénaga de Oro, Córdoba. Inf Quinc Epidemiol Nac. 2002;7:71-4.

14. Acosta J. Urquijo L, Díaz A, Sepúlveda M, Mantilla G, Heredia D, et al. Brote de rickettsiosis en Necoclí, Antioquia, febrero-marzo de 2006. Inf Quinc Epidemiol Nac. 2006;11:177-92.

15. Hidalgo M, Orejuela L, Fuya P, Carrillo P, Hernandez J, Parra E, et al. Rocky Mountain spotted fever, Colombia. Emerg Infect Dis. 2007;13:1058-60.

16. Hidalgo M, Sánchez R, Orejuela L, Hernández J, Walker DH, Valbuena G. Prevalence of antibodies against spotted fever group rickettsiae in a rural area of Colombia. Am J Trop Med Hyg. 2007;77:378-80.

17. Ramírez N, Galvis O, Agudelo AF, Velásquez R, Restrepo LF, Castrillón NK, et al. Tifus murino en el Cairo-Valle ¿Brote o condición endémica emergente?. Investig Andina. 2007;9:5-13.

18. Hidalgo M, Salguero E, de la Ossa A, Sánchez R, Vesga JF, Orejuela L, et al. Murine typhus in Caldas, Colombia. Am J Trop Med Hyg. 2008;78:321-2.

19. Pacheco-García OE, Giraldo MR, Martínez-Duran M, Hidalgo M, Galeano A, Echeverri I, et al. Estudio de brote febril hemorrágico en el corregimiento de Alto de Mulatos - Distrito Especial Portuario de Turbo, Antioquia, enero de 2008. Inf Quinc Epidemiol Nac. 2008;13:145-60.

20. Ríos R, Franco S, Mattar S, Urrea M, Tique V. Seroprevalencia de Leptospira sp., Rickettsia sp. y Ehrlichia sp. en trabajadores rurales del departamento de sucre, Colombia. Infectio. 2008;12:318-23.

21. Hidalgo M, Vesga JF, Lizarazo D, Valbuena G. A survey of antibodies against Rickettsia rickettsii and Ehrlichia chaffeensis in domestic animals from a rural area of Colombia. Am J Trop Med Hyg. 2009;80:1029-30.

22. Padmanabha H, Hidalgo M, Valbuena G, Castaneda E, Galeano A, Puerta H, et al. Geographic variation in risk factors for SFG rickettsial and leptospiral exposure in Colombia. Vector Borne Zoonotic Dis. 2009;9:483-90.

23. Hidalgo M, Miranda J, Heredia D, Zambrano P, Vesga JF, Lizarazo D, et al. Outbreak of Rocky Mountain spotted fever in Córdoba, Colombia. Mem Inst Oswaldo Cruz. 2011;106:117-8.

24. Miranda J, Contreras V, Negrete Y, Labruna MB, Máttar S. Vigilancia de la infección por Rickettsia sp. en capibaras (Hydrochoerus hydrochaeris) un modelo potencial de alerta epidemiológica en zonas endémicas. Biomedica(Bogotá). 2011;31:216-21. 
25. Miranda J, Portillo A, Oteo JA, Mattar S. Rickettsia sp. strain colombianensi (Rickettsiales: Rickettsiaceae): a new proposed rickettsia detected in Amblyomma dissimile (Acari: Ixodidae) from iguanas and free-living larvae ticks from vegetation. J Med Entomol. 2012;49:960-5.

26. Quintero JC, Londoño AF, Díaz FJ, Agudelo-Flórez P, Arboleda M, Rodas JD. Ecoepidemiología de la infección por rickettsias en roedores, ectoparásitos y humanos en el noroeste de Antioquia, Colombia. Biomedica(Bogotá). 2013;33 Supl 1:38-51.

27. Faccini-Martínez ÁA, Forero-Becerra EG, Cortés-Vecino JA, Polo-Teran LJ, Jácome $\mathrm{JH}$, Vargas JJ, et al. Caso probable de fiebre manchada (Rickettsia felis) transmitida por pulgas. Biomedica(Bogotá). 2013;33 Supl 1:9-13.

28. Arroyave E, Londoño AF, Quintero JC, Agudelo-Flórez P, Arboleda M, Díaz FJ, et al. Etiología y caracterización epidemiológica del síndrome febril no palúdico en tres municipios del Urabá antioqueño, Colombia. Biomedica(Bogotá). 2013;33 Supl 1:99-107.

29. Hidalgo M, Montoya V, Martínez A, Mercado M, De la Ossa A, Vélez C, et al. Fleaborne rickettsioses in the north of Caldas province, Colombia. Vector Borne Zoonotic Dis. 2013;13:289-94.

30. Ramírez-Hernández A, Montoya V, Martínez A, Pérez JE, Mercado M, de la Ossa A, et al. Molecular detection of Rickettsia felis in different flea species from Caldas, Colombia. Am J Trop Med Hyg. 2013;89:453-9.
31. Miranda J, Mattar S. Molecular detection of Rickettsia bellii and Rickettsia sp. strain Colombianensi in ticks from Cordoba, Colombia. Ticks Tick Borne Dis. 2014;5:20812 .

32. Londoño AF, Díaz FJ, Valbuena G, Gazi M, Labruna MB, Hidalgo M, et al. Infection of Amblyomma ovale by Rickettsia sp. strain Atlantic rainforest, Colombia. Ticks Tick Borne Dis. 2014;5:672-5.

33. Faccini-Martínez ÁA, Costa FB, Hayama-Ueno TE, Ramírez-Hernández A, CortésVecino JA, Labruna MB, et al. Rickettsia rickettsii in Amblyomma patinoi ticks, Colombia. Emerg Infect Dis. 2015;21:537-9.

34. Barrera S, Martínez S, Tique-Salleg V, Miranda J, Guzmán C, Mattar S. Seroprevalencia de Hantavirus, Rickettsia y Chikungunya en población indígena del municipio de Tuchín, Córdoba. Infectio. 2015;19:75-82.

35. Patiño-Niño JA, Pérez-Camacho PM, Aguirre-Recalde JA, Faccini-Martínez ÁA, Montenegro-Herrera CA, Hidalgo M. Caso probable de tifus murino con falla ventilatoria en una adolescente del área urbana de Cali, Colombia. Infectio. 2015. http://dx.doi.org/10.1016/j.infect.2015.04.006

36. Pérez-Osorio CE, Zavala-Velázquez JE, Arias-León JJ, Zavala-Castro JE. Rickettsia felis as emergent global threat for humans. Emerg Infect Dis. 2008;14:1019-23.

37. Szabó MP, Pinter A, Labruna MB. Ecology, biology and distribution of spotted-fever tick vectors in Brazil. Front Cell Infect Microbiol. 2013;3:27.

Received: 06 August 2015

Accepted: 05 November 2015 